\title{
Cyberloafing Ditinjau Dari Kontrol Diri Dan Kepuasan Kerja
}

\author{
Devy Sofyanty ${ }^{1}$, Tugimin Supriyadi ${ }^{2, *}$ \\ ${ }^{1}$ Fakultas Teknik dan Informatika; Universitas Bina Sarana Informatika; Jl. Kramat Raya No.98 \\ Jakarta Pusat; (021) 21231170; devy.dyy@bsi.ac.id \\ 2 Fakultas Psikologi; Universitas Bhayangkara Jakarta Raya; Jl. Perjuangan 081, Marga Mulya, \\ Bekasi Utara; 02188955882/ +622188955871; e-mail: tugimin.supriyadi@gmail.com \\ * Korespondensi: e-mail: tugimin.supriyadi@gmail.com \\ Submitted: 20/02/2021; Revised: 01/03/2021; Accepted: 12/05/2021; Published: 27/05/2021
}

\begin{abstract}
Cyberloafing is the behavior of employees to use the company or private internet, for activities that have nothing to do with work and are carried out during working hours. Studying cyberloafing behavior is considered very important considering the internet is a daily necessity in carrying out daily tasks so it becomes important to minimize, prevent or even eliminate the factors that cause cyberloafing behavior. This study aims to empirically analyze the effect of self control and job satisfaction on cyberloafing behavior. This research was conducted at the Ministry of Manpower of the Republic of Indonesia. This type of research is quantitative, sampling in this study using purposive sampling techniques. Methods of data collection using questionnaires and interviews. Data were analyzed using multiple linear regression. Based on the analysis results, the following findings are obtained: (1) simultaneously self control and job satisfaction have a negative and significant effect on cyberloafing behavior, (2) partially self control has a negative and significant effect on cyberloafing behavior, (3) partial satisfaction work has a negative and significant effect on cyberloafing.
\end{abstract}

Keywords: Self Control, Job Satisfaction, Cyberloafing

\begin{abstract}
Abstrak
Cyberloafing adalah perilaku karyawan dalam menggunakan fasilitas internet perusahaan atau pribadi, untuk aktivitas yang tidak ada kaitannya dengan pekerjaan dan dilakukan selama jam kerja. Mempelajari perilaku Cyberloafing dinilai sangat penting mengingat internet merupakan kebutuhan sehari-hari dalam menjalankan tugas sehingga menjadi penting untuk meminimalkan, mencegah atau bahkan menghilangkan faktor-faktor penyebab perilaku Cyberloafing. Penelitian ini bertujuan untuk menganalisis secara empiris pengaruh pengendalian diri dan kepuasan kerja terhadap perilaku Cyberloafing. Penelitian ini dilakukan di Kementerian Tenaga Kerja Republik Indonesia. Jenis penelitian ini adalah kuantitatif, teknik pengambilan sampel dalam penelitian ini menggunakan teknik purposive sampling. Metode pengumpulan data menggunakan kuesioner dan wawancara. Analisis data menggunakan regresi linier berganda. Berdasarkan hasil analisis diperoleh temuan sebagai berikut: (1) secara bersama-sama kontrol diri dan kepuasan kerja berpengaruh negatif dan signifikan terhadap perilaku cyberloafing, (2) secara parsial kontrol diri berpengaruh negatif dan signifikan terhadap perilaku cyberloafing, (3) kepuasan kerja secara parsial berpengaruh negatif dan signifikan terhadap cyberloafing.
\end{abstract}

Kata Kunci: Kontrol Diri, Kepuasan Kerja, Cyberloafing 


\section{Pendahuluan}

Perkembangan teknologi, informasi dan komunikasi yang semakin canggih dibarengi dengan kebutuhan akan informasi yang semakin cepat menjadikan internet berperan penting untuk menunjang sekaligus mempermudah pekerjaan. Kemudahan akses internet dapat menambah wawasan dan keterampilan karyawan guna mendukung pekerjaan, pengembangan diri untuk mendukung kemajuan karirnya kelak. Sebagai contoh banyak forum atau website yang menawarkan kursus singkat, gratis atau berbayar dengan biaya terjangkau, serta dipandu oleh tutor yang kompeten dibidangnya. Bahkan ada beberapa kursus yang tahap keahliannya berjenjang hingga memberikan sertifikat kelulusan sebagai bukti kompetensi setelah melewati ujian. Namun sayangnya tidak semua karyawan dapat memanfaatkan fasilitas internet untuk hal-hal positif seperti pada contoh diatas, beberapa karyawan justru mengakses internet di jam kerja hanya untuk kesenangan dan keuntungan pribadinya. Fenonema ini dikenal dengan istilah cyberloafing, perilaku cyberloafing meliputi: membuka website untuk kesenangan pribadi (melihat berita politik, ekonomi, olahraga, hiburan, mengunduh video, lagu, atau film), streaming acara TV atau radio, trading online, game online, belanja online, komik online, kencan online, mengakses atau chatting di media sosial (Facebook, Instagram, Twitter, Whats App), membuka, membaca atau mengirim email pribadi atau kantor untuk urusan pribadi bahkan membuka situs-situs pornografi.

Berdasarkan hasil wawancara dan observasi yang dilakukan peneliti terhadap beberapa orang pegawai di Kementrian Tenaga Kerja Republik Indonesia, dapat disimpulkan motif pegawai melakukan perilaku cyberloafing antara lain: Untuk mengisi waktu luang, membeli barang barang kebutuhan sehari-hari, mencari alternatif berbisnis, menjalin networking dengan teman-teman lama, mencari referensi investasi, kuliner, tempat wisata, hobi atau untuk mengerjakan tugas kuliah atau tugas sekolah anak. Yang menjadi permasalahan adalah apakah perilaku cyberloafing disebabkan oleh minimnya self control sehingga pegawai tidak mampu mengendalikan impuls keinginan/ dorongan untuk melakukan aktivitas lain yang lebih berfaedah untuk pekerjaan maupun institusinya atau minimnya kepuasan kerja yang dialami oleh pegawai sehingga mereka melakukan perilaku yang menyimpang ditempat kerja seperti cyberloafing.

Salah satu faktor yang paling berhubungan dengan munculnya perilaku cyberloafing adalah faktor internal pada individu, yaitu kontrol diri. Kontrol diri menurut (Thalib, 2017) adalah suatu kemampuan individu untuk mengendalikan dorongan-dorongan, baik dari dalam diri maupun dari luar diri individu. Individu yang memiliki kemampuan kontrol diri akan membuat keputusan dan mengambil langkah tindakan efektif untuk menghasilkan sesuatu yang diinginkan dan menghindari akibat yang tidak diinginkan. Pendekatan teori psikologi belajar Skinner mengemukakan bahwa tingkah laku disebabkan dan dipengaruhi oleh faktor eksternal. Tidak ada sesuatu dalam diri manusia, tidak ada bentuk kegiatan internal yang mempengaruhi tingkah laku. Namun betapapun kuatnya stimulus dan penguat eksternal, manusia masih dapat mengubahnya memakai proses kontrol diri (self control). Pengertian kontrol diri ini bukan 
mengontrol kekuatan di dalam "self" tetapi bagaimana self mengontrol variabel-variabel luar yang menentukan tingkah laku dan tingkah laku dapat dikontrol melalui berbagai cara yaitu dengan menghindar, penjenuhan, stimuli yang tidak disukai dan memperkuat diri (Alwisol, 2018). Kontrol diri merupakan kemampuan untuk membimbing tingkah laku sendiri, kemampuan untuk menekan atau merintangi impuls-impuls atau tingkah laku impulsif. Menurut Adeonalia dalam (Liswantiani dan Gregorius Ari Nugrahanta, 2021) mengemukakan bahwa keyakinan individu yang tindakannya akan mempengaruhi perilakunya dan individu sendiri yang dapat mengontrol perilaku merupakan bagian dari kontrol diri.

Kepuasan kerja merupakan gambaran perasaan senang dan tidak senang seorang karyawan terhadap pekerjaan yang dilakukan, kepuasan kerja merupakan respons emosional pegawai terhadap situasi kerja yang ditentukan oleh pencapaian hasil, memenuhi atau melampaui harapan.(Fattah, 2017). Sedangkan menurut Hasibuan dalam (Iskandar dan Yuhansyah, 2018), kepuasan kerja adalah sikap emosional yang menyenangkan dan mencintai pekerjaannya. Pegawai mengungkapkan ketidakpuasan dalam berbagai cara. Sebagai contoh, daripada berhenti bekerja, pegawai dapat mengeluh, mencuri harta benda organisasi, atau mereka menghindari beberapa tanggung jawab pekerjaan mereka (Ulum, 2016).

Cyberloafing adalah tindakan menghabiskan waktu untuk menghindari pekerjaan dengan cara berhubungan dengan internet untuk menyibukkan diri (Utama, dkk 2016). Sedangkan menurut Lim dalam (Shoss, 2020) cyberloafing adalah aktivitas yang dilakukan oleh karyawan untuk menjelajahi internet yang tidak terkait dengan pekerjaan selama jam kerja. atau menggunakan komunikasi melalui email pribadi dan selama jam kerja. Teknologi yang digunakan untuk melakukan cyberloafing dapat dilakukan dengan menggunakan teknologi pribadi bukan hanya teknologi milik instansi saja. Contoh konkret dari praktik cyberloafing menurut Ugrin dkk dalam (Ramadhan dan dan Harlina Nurtjahjanti, 2017) yakni penggunaan email pribadi, jual beli online, gaming, akses website yang menyediakan artikel, tontonan atau gambar dan pornografi (Ugrin, dkk).

Perilaku cyberloafing dikategorikan sebagai perilaku indisipliner, terlebih jika menggunakan fasilitas kantor untuk kepentingan pribadi adalah jelas hal yang dilarang. Karyawan menggunakan jam kerjanya untuk aktivitas yang tidak ada hubungannya dengan pekerjaan bahkan untuk hal-hal yang sifatnya mencari kesenangan pribadi. Hal ini bersifat kontraproduktif, terpecahnya fokus dan konsentrasi pegawai antara pekerjaan dengan perilaku cyberloafing menyebabkan buruknya kualitas kerja yang dihasilkan sehingga mempengaruhi penilaian kinerja karyawan yang bersangkutan yang tentunya juga berdampak pada promosi jabatan karyawan yang bersangkutan. Dampak lain adalah lambatnya pelayanan public sehingga berdampak pula pada citra institusi.

Penelitian yang dilakukan oleh (Moffan \& Seger Handoyo, 2020) yang berjudul "Pengaruh Stres Kerja Terhadap Cyberloafing Dengan Kepuasan Kerja Sebagai Variabel Moderator Pada Karyawan Di Surabaya" diperoleh hasil bahwa stres kerja berpengaruh 
langsung terhadap cyberloafing sedangkan kepuasan kerja tidak memoderasi pengaruh stres kerja terhadap cyberloafing

Berdasarkan pemikiran tersebut maka hipotesis yang diajukan dalam penelitian ini adalah (1) ada pengaruh kontrol diri dengan cyberloafing, (2) ada pengaruh kepuasan kerja dengan cyberloafing dan (3) ada pengaruh kontrol diri dan kepuasan kerja terhadap cyberloafing.

\section{Metode Penelitian}

Metode penelitian yang digunakan dalam penelitian ini adalah kuantitatif yang bersifat eksplanatif. Teknik pengambilan sampel yang digunakan dalam penelitian ini adalah purposive sampling, dimana sampel ditentukan melalui pertimbangan karakteristik tertentu yang telah ditentukan oleh peneliti terhadap subjek yang sesuai dengan tujuan penelitian. Responden dalam penelitian ini adalah para Pengawai Negeri Sipil (PNS) di Kementrian Tenaga Kerja Republik Indonesia, yang berjumlah 100 orang. Adapun karakteristik responden dalam penelitian ini adalah: (1) Berstatus aktif sebagai Pegawai Negeri Sipil (PNS) berusia $20-50$ tahun, (2) Masa kerja minimal 1 (satu) tahun, (3) Memiliki gawai pribadi dan menggunakan peralatan computer dikantor untuk melaksanakan tugas harian, (4) Instansi tempat Pegawai Negeri Sipil (PNS) bekerja tidak membatasi penggunaan akses internet, (5) Bersedia menjadi responden

Alat ukur yang digunakan dalam penelitian ini terdiri dari 3 skala, yaitu skala self control yang berjumlah 15 item, skala kepuasan kerja yang berjumlah 15 item dan skala cyberloafing yang berjumlah 12 item. Semua skala yang digunakan dalam penelitian ini menggunakan model skala Likert. Ketiga skala tersebut menggunakan respon model summated rating dengan 4 jawaban, yakni Sangat Sesuai (SS) diberi skor 4, Sesuai (S) diberi skor 3, Tidak Sesuai (TS) diberi skor 2 dan Sangat Tidak Sesuai (STS) diberi skor 1 untuk pertanyaan favorable. Skor Sangat Sesuai (SS) diberi skor 1, Sesuai (S) diberi skor 2, Tidak Sesuai (TS) diberi skor 3 dan dan Sangat Tidak Sesuai (STS) diberi skor 4. Peneliti tidak memberikan alternatif pilihan raguragu atau netral karena seringkali responden memiliki kecenderungan menjawab ke tengah, dan tidak dapat menunjukkan kecenderungan jawaban subjek ke arah setuju atau tidak setuju sehingga banyak data dan informasi penelitian yang tidak dapat diungkap oleh peneliti. Data yang diperoleh dari kuesioner akan dianalisis menggunakan teknik statistic regresi linier berganda dengan bantuan aplikasi program SPSS (Statistical Package for Social Science)

\section{Hasil Dan Pembahasan}

\subsection{Gambaran Umum Responden}

Berikut adalah pemaparan tentang karakteristik responden dalam penelitian ini. 
Tabel 1. Profil Responden Berdasarkan Jenis Kelamin

\begin{tabular}{ccc} 
& Jenis Kelamin & Jumlah (\%) \\
\cline { 2 - 3 } & Laki-laki & 43 \\
\cline { 2 - 3 } Sumber: Hasil Pengolahan Data (2021) & Perempuan & 57 \\
\cline { 2 - 3 }
\end{tabular}

Berdasarkan output dapat diketahui bahwa sebagian besar responden dalam penelitian ini berjenis kelamin perempuan.

Tabel 2. Profil Responden Berdasarkan Tingkat Pendidikan

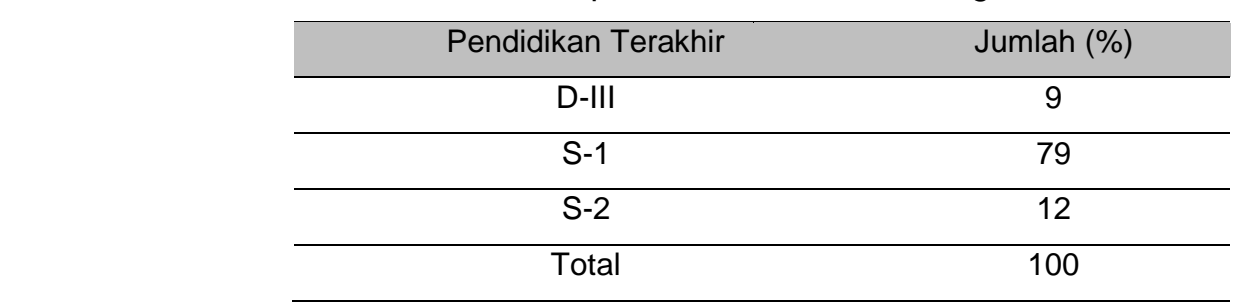

Sumber: Hasil Pengolahan Data (2021)

Pada sebaran data tersebut, responden dengan kategori tingkat pendidikan sarjana paling banyak jumlahnya.

Tabel 3. Profil Responden Berdasarkan Usia

\begin{tabular}{cc}
\hline Usia & Jumlah $(\%)$ \\
\hline $20-30$ tahun & 21 \\
\hline $31-40$ tahun & 65 \\
\hline $41-50$ tahun & 14 \\
\hline Total & 100
\end{tabular}

Sumber: Hasil Pengolahan Data (2021)

Dari keterangan diatas dapat ditarik kesimpulan bahwa sebagian besar responden yang ikut serta dalam penelitian ini berada pada usia produktif.

Tabel 4. Profil Responden Berdasarkan Masa Kerja

\begin{tabular}{ccc}
\hline Masa Kerja & Jumlah (\%) \\
\cline { 2 - 3 } & $0-5$ tahun & 26 \\
\hline $6-10$ tahun & 22 \\
\hline $11-15$ tahun & 39 \\
\hline $16-20$ tahun & 13 \\
\hline Total & 100 \\
\hline
\end{tabular}

Sebaran demografi responden berdasarkan masa kerja, dapat dikatakan bahwa karyawan senior dominan dalam penelitian ini.

\subsection{Uji Validitas}

Validitas suatu instrumen berkaitan dengan ketetapan alat penilaian terhadap konsep yang dinilai sehingga menilai apa yang seharusnya dinilai. Nasution dalam (Faradillah, Ayu, dkk , 2020) mengatakan validitas data penelitian adalah apa yang diamati peneliti, sesuai dengan apa yang sesungguhnya ada dalam dunia nyata. Apabila hal tersebut tidak sesuai atau sama 
maka instrumen sebagai pengumpul data dan orang yang menggunakannya tidak tepat dan hasilnya pun tidak akan sesuai atau tidak memenuhi syarat validitas.

Tabel 5. Uji Validitas

\begin{tabular}{ccc} 
Variabel & Correced Item Total & Keterangan \\
& & \\
\hline Kontrol Diri & $0.315-0.671$ & Valid \\
\hline Kepuasan Kerja & $0.320-0.473$ & Valid \\
\hline Cyberloafing & $0.346-0.676$ & Valid
\end{tabular}

Sumber: Hasil Pengolahan Data (2021)

Pengujian validitas dalam penelitian ini dilakukan dengan cara membandingkan antara nilai $r$ hitung dengan $r$ tabel, dengan asumsi setiap indikator harus memiliki nilai $r$ hitung lebih besar dibandingkan dengan $r$ tabel. Berdasarkan output diperoleh bahwa seluruh item dalam skala kontrol diri adalah valid, item mempunyai nilai daya beda item yang bergerak dari 0.315 sampai 0.671 . Sedangkan untuk skala variabel kepuasan kerja, dari 15 butir item diperoleh hasil bahwa seluruh item dinyatakan valid dengan nilai daya beda item yang bergerak dari 0.320 sampai 0.473 . Hasil serupa untuk variabel cyberloafing diperoleh hasil semua item valid, dari 12 item diperoleh nilai daya beda item yang bergerak dari 0.346 sampai 0.676 .

\subsection{Uji Reliabilitas}

Reliabilitas adalah konsistenti atau keajegan hasil penelitian, reliabilitas merujuk pada pengertian bahwa suatu instrumen cukup dapat dipercaya untuk digunakan sebagai alat pengumpul data karena instrumen tersebut sudah baik. Suatu instrumen dikatakan reliabel jika selalu memberikan hasil yang sama bila diujikan pada kelompok yang sama pada waktu atau kesempatan yang berbeda (Faradillah, Ayu, dkk 2020). Reliabilitas dalam penelitian ini menggunakan metode Alpha Cronbach.

Tabel 6. Uji Reliabilitas

\begin{tabular}{|c|c|c|}
\hline Variabel & $\begin{array}{l}\text { Cronbach's } \\
\text { Alpha }\end{array}$ & Keterangan \\
\hline Kontrol Diri & 0.893 & Reliabel \\
\hline Kepuasan Kerja & 0.902 & Reliabel \\
\hline Cyberloafing & 0.879 & Reliabel \\
\hline
\end{tabular}

Sumber: Hasil Pengolahan Data (2021)

Perhitungan reliabilitas terhadap alat ukur kontrol diri, kepuasan kerja dan cyberloafing menghasilkan koefisien reliabilitas lebih dari 0.6 sehingga dapat disimpulkan bahwa ketiga variabel tersebut reliabel sebagai alat ukur.

\subsection{Uji Normalitas}

Pengujian normalitas bertujuan untuk menguji apakah dalam model regresi, variabel bebas dan variabel terikat, keduanya memiliki distribusi normal atau tidak. 


\section{Normal P-P Plot of Regression Standardized Residual}

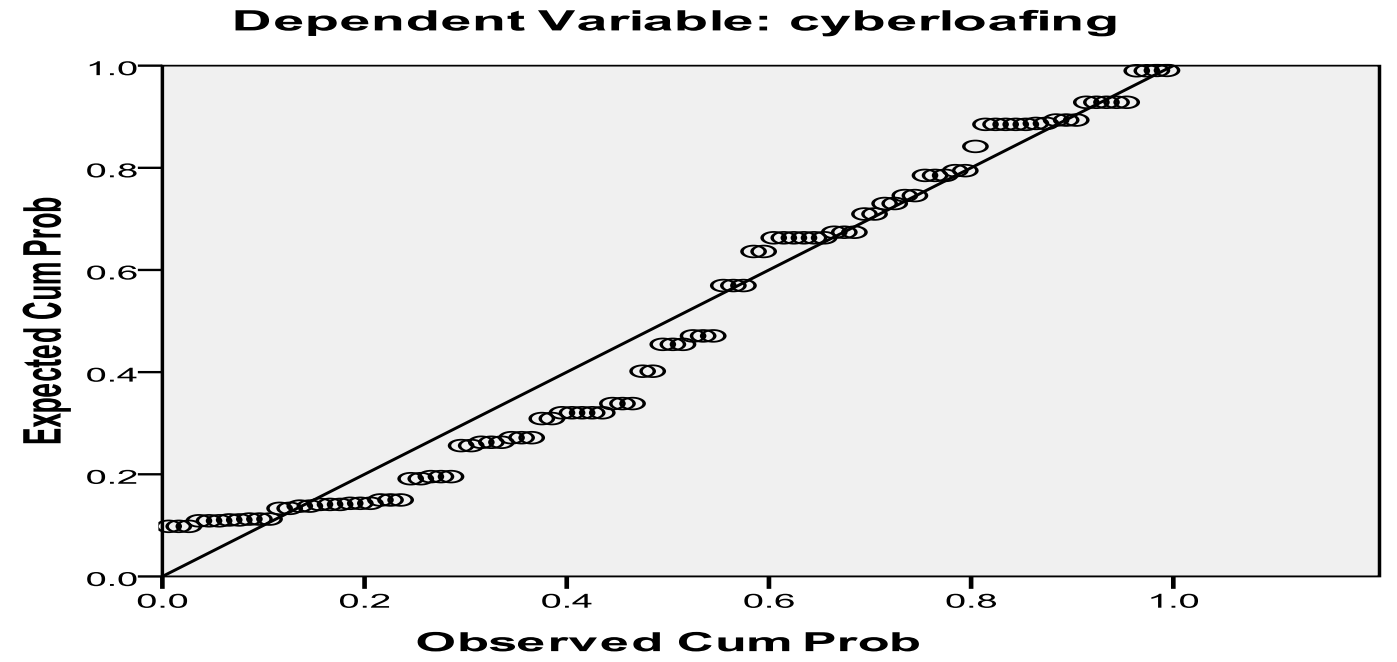

Sumber: Hasil Penelitian (2021)

\section{Gambar 1. Uji Normalitas}

Pada Gambar 1 menunjukkan bahwa titik-titik ploting mengikuti dan mendekati garis diagonalnya maka dapat disimpulkan bahwa data dalam penelitian ini sudah terdistribusi dengan normal atau sudah memenuhi asumsi normalitas.

Tabel 7. Uji Statistik

\begin{tabular}{|c|c|c|}
\hline Uji Statistik & Indikasi & Output \\
\hline Kolmogorov- Smirnov & $\begin{array}{l}\text { Asymp. } \\
\text { Sig }\end{array}$ & .124 \\
\hline Multikolinearitas & Tollerance & $\begin{array}{l}X 1=0.890 \\
X 2=0.890\end{array}$ \\
\hline & VIF & $\begin{array}{l}X 1=1.123 \\
X 2=1.123\end{array}$ \\
\hline Glejser & Sig & $\begin{array}{l}X 1=.447 \\
X 2=.466\end{array}$ \\
\hline Koefisien Determinasi & $\mathrm{R}^{2}$ & 0.655 \\
\hline Uji F & $\begin{array}{c}\text { Nilai F } \\
\text { Sig }\end{array}$ & $\begin{array}{l}161.213 \\
.000\end{array}$ \\
\hline
\end{tabular}

Sumber: Hasil Pengolahan Data (2021)

Pengujian normalitas dalam penelitian ini menggunakan Kolmogorov - Smirnov Test, diperoleh nilai Asymp 0.124 sehingga dapat ditarik kesimpulan bahwa data terdistribusi normal dan sampel penelitian mewakili populasi. Dengan demikian asumsi atau persyaratan normalitas dalam regresi sudah terpenuhi dan dapat digunakan untuk pengambilan keputusan. 


\subsection{Uji Multikolinearitas}

Multikolinearitas dapat terjadi jika adanya hubungan linier yang sempurna atau hampir sempurna diantara beberapa atau seluruh variabel independen dalam model regresi. Hasil uji multikolinearitas menunjukkan nilai tollerance variabel independen, yaitu kontrol diri dan kepuasan kerja $>0.10$. Sementara nilai VIF yang didapat $<10$. Ini berarti model persamaan regresi terbebas dari kasus multikolinearitas sehingga mempertegas kelayakan model regresi yang dijalankan.

\subsection{Uji Heteroskedastisitas}

Uji heteroskedastisitas bertujuan untuk menguji apakah dalam model regresi terjadi ketidaksamaan variance residual satu pengamatan ke pengamatan yang lain.

\section{Scatterplot}

\section{Dependent Variable: cyberloafing}

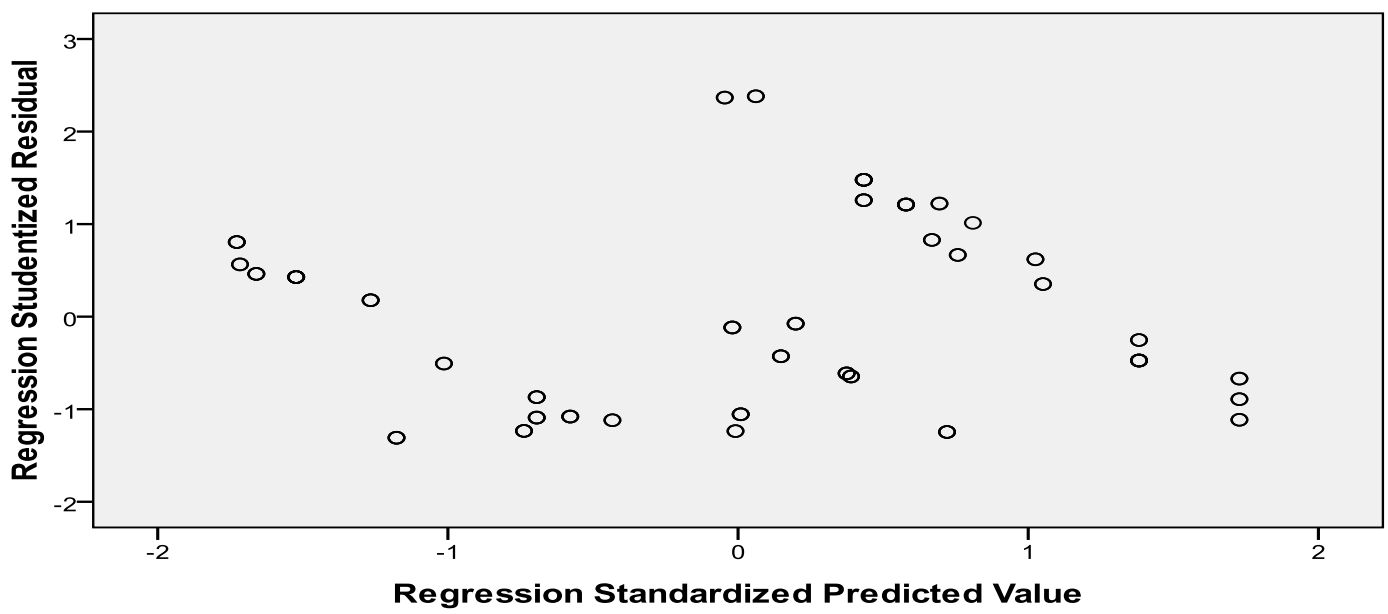

Sumber: Hasil Penelitian (2021)

\section{Gambar 2 Uji Heteroskedastisitas}

Pada Gambar 2 menunjukkan grafik scatterplot antara nilai prediksi variabel independen dengan variabel residualnya diperoleh hasil tidak adanya pola yang jelas, serta titik-titik tidak menyebar diatas dan dibawah angka 0 pada sumbu Y. Hal ini mengindikasikan tidak terjadi heteroskedastisitas dalam penelitian ini. Hal ini diperkuat dengan pengujian heteroskedastisitas menggunakan Uji Glejser, seperti yang tampak pada Tabel 7 menunjukkan bahwa model uji terbebas dari heteroskedastisitas. Hal ini terbukti dengan nilai signifikansi yang lebih besar dari a $5 \%$.

\subsection{Koefisien Determinasi $\left(\mathbf{R}^{2}\right)$}

Koefisien determinasi $\left(R^{2}\right)$ bertujuan untuk mengetahui seberapa besar kemampuan variabel bebas menjelaskan pengaruhnya terhadap variabel terikat. Berdasarkan output seperti yang ditunjukkan pada tabel 7 diperoleh nilai $R$ Square $\left(R^{2}\right)$ menunjukkan koefisien determinasi yang bernilai 0.655 persentase sumbangan pengaruh kontrol diri dan kepuasan kerja terhadap 
perilaku cyberloafing sebesar $65,5 \%$ sedangkan sisanya sebesar $34,5 \%$ dipengaruhi oleh variabel lain yang tidak dimasukkan dalam penelitian ini.

\subsection{Uji Signifikansi Simultan (Uji Statistik F)}

Pengujian hipotesis secara simultan (Uji F) digunakan untuk mengetahui besarnya pengaruh yang bermakna dari variabel bebas secara bersama-sama (simultan) terhadap variabel terikat. Berdasarkan output seperti yang dilihat pada Tabel 7, diperoleh nilai F hitung sebesar 161.213 dengan nilai signifikansi $0.000<0.05$ maka dapat disimpulkan bahwa kontrol diri dan kepuasan kerja secara bersama-sama berpengaruh terhadap perilaku cyberloafing.

\subsection{Uji Parameter Individual (Uji T)}

Tujuan dari Uji $\mathrm{T}$ adalah untuk mengetahui apakah secara parsial variabel bebas berpengaruh signifikan terhadap variabel terikat.

Tabel 8. Uji T

\begin{tabular}{|c|c|c|c|c|c|}
\hline \multirow[b]{3}{*}{ Model } & \multicolumn{5}{|c|}{ Standa } \\
\hline & \multicolumn{3}{|c|}{$\begin{array}{l}\text { Unstandardized rdized } \\
\text { Coefficients Coefficients }\end{array}$} & \multirow[b]{2}{*}{$\mathrm{t}$} & \multirow[b]{2}{*}{ Sig. } \\
\hline & $B$ & Std. Error & Beta & & \\
\hline (Constant) & 147.166 & 5.602 & & 26.273 & .000 \\
\hline Self control & -.956 & .055 & -.892 & -17.230 & .000 \\
\hline Kepuasan kerja & -.740 & .071 & -.542 & -10.474 & .000 \\
\hline
\end{tabular}

Hipotesis 1 pengaruh self control terhadap Cyberloafing. Variabel kontrol diri memiliki nilai $t$ hitung sebesar -17.230 dengan nilai signifikansi $0.000<0.05$, sehingga dapat ditarik kesimpulan bahwa variabel kontrol diri memiliki pengaruh negatif dan signifikan terhadap perilaku cyberloafing.

Hipotesis 2 pengaruh kepuasan kerja terhadap Cyberloafing. Berdasarkan output diperoleh nilai t hitung variabel kepuasan kerja sebesar -10.474 dengan nilai signifikansi 0.000 $<0.05$. Hal ini menunjukkan bahwa kepuasan kerja berpengaruh negatif dan signifikan terhadap perilaku cyberloafing.

Persamaan linier antara kontrol diri dan kepuasan kerja terhadap perilaku Cyberloafing adalah sebagai berikut:

$$
Y^{\wedge}=147.166-0.956 X_{1}-0.740 X_{2}
$$

Konstanta a sebesar 147.166 bernilai positif, yang berarti apabila kontrol diri dan kepuasan kerja dianggap konstan atau tetap, maka rata-rata perilaku cyberloafing yang dilakukan pegawai adalah 147.166. Hal ini menunjukkan bahwa cyberloafing yang dilakukan pegawai tergolong tinggi karena a melebihi 1 , untuk itu semua variabel bebas yang mempengaruhi cyberloafing dalam penelitian ini sebaiknya dikondisikan, diminimalisir atau bahkan dihilangkan

Koefisien regresi variabel kontrol diri (b1) adalah sebesar -0.956, menunjukkan hubungan negative (berlawanan arah) antara kontrol diri dengan perilaku cyberloafing. Hasil ini 
menunjukkan bahwa semakin rendah kontrol diri maka akan diikuti dengan meningkatnya perilaku cyberloafing. Demikian pula sebaliknya jika semakin tinggi kontrol diri maka akan diikuti dengan menurunnya perilaku cyberloafing. Berdasarkan analisis regresi dapat ditarik kesimpulan bahwa setiap penurunan $1 \%$ kontrol diri maka perilaku cyberloafing akan naik sebesar $95.6 \%$ dengan asumsi variabel bebas lainnya yakni kepuasan kerja bernilai konstan atau tetap. Sedangkan untuk koefisien variable kepuasan kerja bernilai -0.740 , hal ini menunjukkan bahwa setiap penurunan $1 \%$ kepuasan kerja maka perilaku cyberloafing akan naik sebesar $74,0 \%$ dengan asumsi variable bebas lainnya yakni kontrol diri bernilai tetap.

\section{Kesimpulan}

Berdasarkan hasil penelitian yang dilakukan kepada 100 orang Pegawai Negeri Sipil (PNS) Kementrian Tenaga Kerja Republik Indonesia dapat disimpulkan bahwa ada pengaruh negatif dan signifikan kontrol diri terhadap perilaku cyberloafing. Hal ini berarti semakin rendah kontrol diri yang dimiliki oleh pegawai maka semakin tinggi pula perilaku cyberloafing yang dilakukan. Sebaliknya semakin tinggi kontrol diri maka semakin rendah perilaku cyberloafing. Terbukti ada pengaruh negatif dan signifikan kepuasan kerja terhadap perilaku cyberloafing. $\mathrm{Hal}$ ini berarti semakin rendah kepuasan kerja yang dimiliki oleh pegawai maka akan semakin tinggi perilaku cyberloafing, sebaliknya semakin tinggi kepuasan kerja maka akan menurunkan perilaku cyberloafing. Terbukti ada pengaruh negatif dan signifikan kontrol diri dan kepuasan kerja terhadap perilaku cyberloafing, hal ini mengindikasikan bahwa semakin rendah kontrol diri dan kepuasan kerja yang dimiliki pegawai maka akan semakin naik perilaku cyberloafing yang dilakukan oleh pegawai.

Organisasi diharapkan dapat lebih asertif dalam menerapkan disiplin terkait dengan penggunaan internet. diantaranya dengan meningkatkan pengawasan terhadap pegawai serta adanya aturan dan sanksi yang jelas, tegas serta penerapan sanksi yang segera setelah terjadinya cyberloafing. Hal ini dilakukan untuk menimbulkan efek jera sekaligus pembelajaran untuk pegawai yang lain. Sanksinya pun bervariatif berdasarkan intensitas pegawai melakukan cyberloafing. Sanksi dapat berupa teguran, peringatan tertulis sampai pemblokiran fasilitas internet untuk situs-situs tertentu. Bagi pegawai disarankan untuk lebih mengembangkan rasa kesadaran akan tanggung jawab, loyalitas, komitmen, serta keterikatan terhadap pekerjaan sehingga nilai-nilai tersebut mampu menginternalisasi ke dalam diri pegawai yang bersangkutan dan menjadi panutan sekaligus memotivasi pegawai untuk meningkatkan kinerja maupun kompetensi diri. Hal ini dapat ditumbuhkan melalui serangkaian kegiatan seperti: pelatihan, seminar, workshop, gathering. Perlunya melatih sikap profesionalitas, asertif serta konsisten untuk menggunakan fasilitas internet sebatas keperluan mengerjakan tugas kantor. Perlunya bagian biro kepegawaian memberikan layanan konseling, maupun psikoterapi untuk mengubah sikap dan perilaku karyawan ke arah positif untuk memperbaiki disiplin karyawan.

Organisasi diharapkan mampu memfasilitasi lingkungan kerja yang mendukung tercapainya kepuasan kerja karyawan, hal tersebut dapat dilakukan antara lain dengan 
memberdayakan potensi pegawai (hard skill maupun soft skill), pemberian tugas yang bervariatif dan menantang. Skema kompensasi diharapkan mampu memberikan stimulus kepada karyawan untuk meningkatkan kepuasan kerja pegawai, diantaranya berupa gaji dan insentif yang kompetitif, promosi jabatan yang adil dan transparan, melibatkan pegawai dalam bentuk dukungan kepesertaan, sumbangsih pendapat, saran untuk kemajuan organisasi. Perlunya manajemen atau atasan memantau kepuasan kerja pegawai, diantaranya dengan memperhatikan kinerja anak buah. Jika ada perilaku yang tidak biasa, seperti: kurang bersemangat dalam bekerja, kurangnya motivasi kerja, kerja malas-malasan, kinerja yang menurun maka atasan dapat mengajak bicara baik-baik untuk sekedar sharing sambil membantu mencarikan jalan keluar atau dapat juga direferensikan ke biro kepegawaian untuk konseling

Implikasi teoritis untuk penelitian selanjutnya hendaknya dapat memperluas Objek penelitian pada bidang pekerjaan yang lain, dengan karakteristik subjek yang berbeda, seperti pada karyawan Badan Usaha Milik Negara (BUMN) atau Badan Usaha Milik Daerah (BUMD), perusahaan swasta maupun asing, karyawan dengan status kontrak atau karyawan out source. Peneliti selanjutnya juga dapat menggunakan teknik analisis data yang berbeda dan menambah jumlah sampel yang digunakan sehingga dapat memperkaya hasil penelitian. Sedangkan untuk penelitian selanjutnya juga dapat menambahkan variabel lain predictor munculnya perilaku cyberloafing, seperti locus of control, kecerdasan emosional, kecerdasan adversitas, persepsi dukungan organisasi, psychological well being, konformitas, iklim organisasi, gaya kepemimpinan, motivasi kerja, stres kerja, persepsi terhadap beban kerja, konflik peran, etos kerja, komitmen organisasi, dll sehingga dapat mengungkap banyak wacana dengan sudut pandang yang lebih luas.

\section{Daftar Pustaka}

Alwisol. (2018). Psikologi Kepribadian. Malang: Universitas Muhammadiyah Malang. Universitas Muhammadiyah Malang.

Faradillah, Ayu, dkk. (2020). Evaluasi Proses \& Hasil Belajar Matematika. Uhamka Press.

Fattah, H. (2017). Kepuasan Kerja dan Kinerja Pegawai. Elmatera.

Iskandar dan Yuhansyah. (2018). Pengaruh Motivasi dan Ketidakamanan Kerja terhadap Penilaian Kerja yang Berdampak Kepada Kepuasan Kerja. Media Sahabat.

Liswantiani, E. dan Gregorius Ari Nugrahanta (2021). Mengoptimalkan Karakter Kontrol Diri Anak dengan Sarana Permainan Tradisional. CV Resitasi Pustaka.

Moffan. (2020). Pengaruh Stres Kerja Terhadap Cyberloafing Dengan Kepuasan Kerja Sebagai Variabel Moderator Pada Karyawan Di Surabaya". Jurnal Magister Psikologi Universitas Medan Area, 12(1).

Ramadhan, H. I. dan Harlina Nurtjahjanti (2017). Hubungan Antara Persepsi Terhadap Beban Kerja Dengan Cyberloafing Pada Karyawan Biro Administrasi Umum Dan Keuangan Universitas Diponegoro. Jurnal Empati, 6(1), 215-220. 
Shoss, M. K. \& L. A. W. (2020). The Cambridge Handbook of The Changing Nature of Work. Cambridge University Press.

Thalib, S. B. (2017). Psikologi Pendidikan Berbasis Analisis Empiris Aplikatif. Kencana.

Ulum, C. (2016). Perilaku Organisasi: Menuju Orientasi Pemberdayaan. UB Press.

Utama. (2016). Psikologi dan Teknologi Informasi: Seri Sumbangan Pemikiran Psikologi untuk Bangsa. Himpunan Psikologi Indonesia. 